\title{
Nitrous Oxide Emission from Organic Fertilizer and Controlled Release Fertilizer in Tea Fields
}

\author{
Meihua Deng ${ }^{1}$, Mudan Hou ${ }^{2}$, Naoko Ohkama-Ohtsu ${ }^{3}$, Tadashi Yokoyama ${ }^{3}$, Haruo Tanaka ${ }^{3}$, \\ Kenta Nakajima ${ }^{4}$, Ryosuke Omata ${ }^{4}$ and Sonoko Dorothea Bellingrath-Kimura ${ }^{5,6, *}$ \\ 1 College of Environmental and Resource Science, Zhejiang University, 866 Yuhangtang Road, \\ Hangzhou 310058, China; meihuad@163.com \\ 2 Graduate School of Agriculture, Department of Biological Production Science, \\ Tokyo University of Agriculture and Technology, 3-5-8 Saiwai-cho, Fuchu, Tokyo 183-8509, Japan; \\ mudan_111@yahoo.co.jp \\ 3 Institute of Agriculture, Tokyo University of Agriculture and Technology, 3-5-8 Saiwai-cho, Fuchu, \\ Tokyo 183-8509, Japan; nohtsu@cc.tuat.ac.jp (N.O.-O.); tadashiy@cc.tuat.ac.jp (T.Y.); haruo@cc.tuat.ac.jp (H.T.) \\ 4 Green Tea Laboratory, Saitama Prefectural Agriculture and Forestry Research Center, 244-2 Kamiyaganuki, \\ Iruma, Saitama 358-0042, Japan; nakajima.kenta@pref.saitama.lg.jp (K.N.); \\ omata.ryosuke@pref.saitama.lg.jp (R.O.) \\ 5 Life Science, Humboldt University of Berlin, Berlin 14195, Germany \\ 6 Leibniz Centre for Agricultural Landscape Research, Institute of Land Use Systems, Eberswalder str. 84, \\ 15374 Muencheberg, Germany \\ * Correspondence: belks@zalf.de; Tel.: +49-33432-82310
}

Academic Editor: Ryusuke Hatano

Received: 8 February 2017; Accepted: 9 March 2017; Published: 21 March 2017

\begin{abstract}
A field experiment was conducted for two years in the Green Tea Laboratory of Saitama Prefectural Agriculture and Forestry Research Center, Iruma, Saitama, Japan from March 2014 to December 2015. Controlled release fertilizers (CRF) or organic fertilizers (ORG), which are a mixture of chicken manure and oil cake, were applied with the amount of $450 \mathrm{~kg} \cdot \mathrm{N} \cdot \mathrm{ha}^{-1} \cdot \mathrm{year}^{-1}$ in 2014 and $397 \mathrm{~kg} \cdot \mathrm{N} \cdot \mathrm{ha}^{-1} \cdot$ year $^{-1}$ in 2015 . Nitrous oxide $\left(\mathrm{N}_{2} \mathrm{O}\right)$ emissions from soil in green tea fields were measured by the closed chamber method. The results showed that CRF has significantly lower $\mathrm{N}_{2} \mathrm{O}$ compared to ORG. The cumulative $\mathrm{N}_{2} \mathrm{O}$ emissions from CRF accounted for $51 \%$ of $\mathrm{N}_{2} \mathrm{O}$ emissions from ORG fields and $138 \%$ of control with no fertilizer treatment. The $\mathrm{N}_{2} \mathrm{O}$ flux from the row was higher than that under the canopy, since fertilizer was applied on the row. However, the total emission from the area between the rows was lower than that under the canopy because the area ratio between the row and canopy was 1:5.
\end{abstract}

Keywords: controlled release fertilizer (CRF); organic fertilizer (ORG); nitrous oxide; row; canopy

\section{Introduction}

Tea (Camellia sinensis) is widely cultivated in Japan [1]. To obtain good tea leaf yield and good quality tea, tea fields generally accept a large amount of nitrogen $(\mathrm{N})$ fertilizer in Japan [2] and the $\mathrm{N}$ application rate has reached a range of $450-1000 \mathrm{~kg} \cdot \mathrm{N} \cdot \mathrm{ha}^{-1} \cdot \mathrm{year}^{-1}$ [3-5]. The high amount of $\mathrm{N}$ application rate has led to a large $\mathrm{N}$ loss with nitrate $\left(\mathrm{NO}_{3}{ }^{-}\right)$leaching, as well as nitrogen dioxide $\left(\mathrm{N}_{2} \mathrm{O}\right)$ emission [6,7]. Akiyama et al. [8] have reported that the $\mathrm{N}_{2} \mathrm{O}$ emission from tea fields in Japan was up to $2.82 \% \pm 1.80 \%$ of input $\mathrm{N}$, which is four times higher than that of upland fields, at $0.62 \% \pm 0.48 \%$ of input $\mathrm{N}$ and nine times greater than paddy fields, at $0.31 \% \pm 0.31 \%$. According to NIES 2012 [9] reports, the $\mathrm{N}_{2} \mathrm{O}$ emission from tea fields accounts for approximately $16 \%$ of the total $\mathrm{N}_{2} \mathrm{O}$ emission from Japanese agricultural fields. Therefore, mitigation of $\mathrm{N}_{2} \mathrm{O}$ emission from tea fields in Japan is urgently needed. 
To reduce $\mathrm{N}_{2} \mathrm{O}$ emission and improve crop $\mathrm{N}$, efficient, controlled-release fertilizer (CRF) has been introduced into many crops [10]. The CRF is coated with polymers, sulfur, or a combination of both [11]. Compared to common chemical fertilizers, which immediately release $\mathrm{N}$ into the soil, controlled-release fertilizers and organic fertilizers show various $\mathrm{N}$ release patterns and has different $\mathrm{N}_{2} \mathrm{O}$ patterns [12]. Quite a number of studies indicate that CRF can mitigate $\mathrm{N}_{2} \mathrm{O}$ emission from upland and paddy soils [13-15]. However, there is the little information on $\mathrm{N}_{2} \mathrm{O}$ emission from tea fields under CRF. Compared to common chemical fertilizer, organic fertilizer (ORG) has a slow $\mathrm{N}$ release pattern. Hence, ORG can probably mitigate the $\mathrm{N}_{2} \mathrm{O}$ gases emissions due to avoiding high emission peaks $[16,17]$. Many studies have been conducted to compare $\mathrm{N}_{2} \mathrm{O}$ emissions from CRF and common chemical fertilizers in various crop systems [18,19], emphasizing the advantage of CRF to common chemical fertilizers based on the slow release pattern. However, little work has been done to compare $\mathrm{N}_{2} \mathrm{O}$ emissions from CRF and ORG.

The tea plant in Japan is cultivated as continuous canopies in rows. The distance between rows of tea plants commonly ranges between 1.5 and $2.0 \mathrm{~m}$. The tea canopy covers a width of $1.0-1.5 \mathrm{~m}$ and leaves bare soil between the rows. All fertilizers are applied to the bare soil between the rows of tea plants [20]. No fertilizer is applied to the soil area under the canopy. While the soil in the rows is compacted due to management practices, the soil under the canopy is undisturbed. Higher $\mathrm{N}_{2} \mathrm{O}$ flux from the soil under the canopy occurs when there is heavy rainfall $[20,21]$. The use of CRF is supposed to reduce the $\mathrm{N}_{2} \mathrm{O}$ flux for the row, as well as for under the canopy; however, no research has been conducted yet.

Therefore, the aims of this research were: (1) to evaluate the effect of CRF and ORG on $\mathrm{N}_{2} \mathrm{O}$ emissions from tea fields; and (2) to evaluate differences in $\mathrm{N}_{2} \mathrm{O}$ emissions from soils in rows and under the canopy under different fertilizer applications.

\section{Materials and Methods}

\subsection{Site Description}

The study site was located at the Green Tea Laboratory of Saitama Prefectural Agriculture and Forestry Research Center, Iruma, Saitama, Japan $\left(35^{\circ} 80^{\prime} \mathrm{N}, 139^{\circ} 34^{\prime} \mathrm{E}\right)$. The annual mean air temperature is $14.3^{\circ} \mathrm{C}$, and the total annual precipitation averages $1481.6 \mathrm{~mm}$, considering a 30 year period of observations (1981-2010) by the Japan Meteorological Agency. Tea plant variety Yabukita was planted in 1971. Tea plants were trimmed (spring trimming) on 4 April 2014 and 30 March 2015, and all trimmed leaves and branches were removed from the row, while the leaves and branches that fell into tea bushes remained inside. The tea leaf harvesting times were on 29 May and 15 July in 2014, and on 15 May and 13 July in 2015. The soil was a Silandic Andosol [21]. The basic soil characteristics are shown in Table 1.

Table 1. Physicochemical characteristics of tea soils.

\begin{tabular}{|c|c|c|c|c|c|c|}
\hline Location & $\mathrm{pH}$ & $\begin{array}{c}\mathrm{NH}_{4}{ }^{+}-\mathrm{N} \\
\left(\mathrm{mg} \cdot \mathrm{kg}^{-1}\right)\end{array}$ & $\begin{array}{c}\mathrm{NO}_{3}{ }^{-}-\mathrm{N} \\
\left(\mathrm{mg} \cdot \mathrm{kg}^{-1}\right)\end{array}$ & $\begin{array}{c}\text { Total C } \\
\left(\mathrm{g} \cdot \mathrm{kg}^{-1}\right)\end{array}$ & $\begin{array}{c}\text { Total N } \\
\left(\mathrm{g} \cdot \mathrm{kg}^{-1}\right)\end{array}$ & $\begin{array}{c}\text { Bulk Density } \\
\left(\mathrm{g} \cdot \mathrm{cm}^{-3}\right)\end{array}$ \\
\hline Row & 3.63 & 1.24 & 6.20 & 117.6 & 11.0 & 0.46 \\
\hline Canopy & 3.81 & 1.74 & 7.92 & 104.7 & 10.5 & 0.41 \\
\hline
\end{tabular}

Note: $\mathrm{NH}_{4}{ }^{+}-\mathrm{N}_{\text {and }} \mathrm{NO}_{3}{ }^{-}-\mathrm{N}$ denotes ammonium-nitrogen and nitrate-nitrogen respectively. $\mathrm{N}, \mathrm{C}$ represent nitrogen and carbon.

\subsection{Experimental Design}

The area of the study site was $832 \mathrm{~m}^{2}(47 \mathrm{~m} \times 17.7 \mathrm{~m})$ including a buffer $415.8 \mathrm{~m}^{2}$. The remaining area was laid out in a randomized complete block design into three treatments with six replications. The length and wide of tea canopy is $11 \mathrm{~m}$ and $1.5 \mathrm{~m}$ for each plot. The row space was $0.3 \mathrm{~m}$. Both rows along the canopy were fertilized, there were buffer canopies among the treatments. The treatments 
consisted of no fertilizer as control (denoted as CONT), controlled-released chemical fertilizer (CRF), and organic fertilizer (ORG) treatments. The controlled-released fertilizer in this experiment was sulfur-coated urea (Meister 180-days type, Jcamagri Co., Ltd., Tokyo, Japan), phosphorus $\left(\mathrm{P}_{2} \mathrm{O}_{5}\right)$ (Nitto FC Co., Ltd., Nagoya, Japan) and sulfur-coated potash $\left(\mathrm{K}_{2} \mathrm{O}\right)$ (Meister SOP, Jcam Agri. Co., Ltd., Tokyo, Japan). Organic fertilizers were oil cake (Daiwa Co., Ltd., Hyogo, Japan), and fermented chicken manure (Corporation Omiya Green Service, Omiya, Japan). The nutrition content of organic fertilizer has shown in Table 2. The application rates of $\mathrm{N}, \mathrm{P}_{2} \mathrm{O}_{5}$, and $\mathrm{K}_{2} \mathrm{O}$ in each treatment were $450 \mathrm{~kg} \cdot \mathrm{N} \cdot \mathrm{ha}^{-1} \cdot$ year $^{-1}, 225 \mathrm{~kg} \cdot \mathrm{P}_{2} \mathrm{O}_{5} \cdot \mathrm{ha}^{-1} \cdot \mathrm{year}^{-1}$, and $225 \mathrm{~kg} \cdot \mathrm{K}_{2} \mathrm{O} \cdot \mathrm{ha}^{-1} \cdot \mathrm{year}^{-1}$ in 2014 , and $397 \mathrm{~kg} \cdot \mathrm{N} \cdot \mathrm{ha}^{-1} \cdot$ year $^{-1}, 466 \mathrm{~kg} \cdot \mathrm{P}_{2} \mathrm{O}_{5} \cdot \mathrm{ha}^{-1} \cdot$ year $^{-1}$, and $419 \mathrm{~kg} \cdot \mathrm{K}_{2} \mathrm{O} \cdot \mathrm{ha}^{-1} \cdot$ year $^{-1}$ in 2015 . The total amount of fertilizer was split in spring and autumn applications with a rate of 2:1. Fertilizers were applied on 18 March and 2 September in 2014, and on 10 March and 15 September in 2015. All fertilizers were applied as a band application between canopies by incorporation to a depth of $15 \mathrm{~cm}$ in soil using a walk-behind rotary tiller.

Table 2. Chemical component of organic fertilizers.

\begin{tabular}{|c|c|c|c|c|c|c|c|c|c|}
\hline & N (\%) & $\mathbf{P}(\%)$ & K (\%) & $\mathrm{C}(\%)$ & $\mathrm{C} / \mathrm{N}$ & $\begin{array}{c}\text { Water } \\
\text { Content }(\%)\end{array}$ & $\begin{array}{c}\mathrm{NH}_{4}{ }^{+}-\mathrm{N} \\
\left(\mathrm{mg} \cdot \mathrm{kg}^{-1}\right)\end{array}$ & $\begin{array}{c}\mathrm{NO}_{3}{ }^{-}-\mathrm{N} \\
\left(\mathrm{mg} \cdot \mathrm{kg}^{-1}\right)\end{array}$ & $\mathrm{pH}$ \\
\hline Chickenmanure 2014 \& 2015 & 2.64 & 5.96 & 3.95 & 27.9 & 10.6 & 22.4 & 4.02 & 0.04 & 8.1 \\
\hline Oil cake in 2014 & 12.2 & 2.56 & 2.87 & 20.8 & 1.70 & 14.6 & 16.1 & 0.83 & 7.4 \\
\hline Oil cake in 2015 & 12.1 & 3.02 & 3.93 & 21.6 & 1.78 & 14.7 & 16.0 & 0.91 & 7.2 \\
\hline
\end{tabular}

Note: $\mathrm{N}, \mathrm{P}, \mathrm{K}, \mathrm{C}$ denotes nitrogen, $\mathrm{P}_{2} \mathrm{O}_{5}, \mathrm{~K}_{2} \mathrm{O}$ and carbon. $\mathrm{C} / \mathrm{N}$ means the ratio of carbon and nitrogen, $\mathrm{NH}_{4}{ }^{+}-\mathrm{N}$ and $\mathrm{NO}_{3}{ }^{-}-\mathrm{N}$ represents ammonium-nitrogen and nitrate-nitrogen respectively.

\subsection{Gas Sample Collection and Analysis}

The gas sample was conducted by the chamber method. The chambers used in this study comprised a polyvinyl non-transparent circle cylinder with a diameter and height of $20 \mathrm{~cm} \mathrm{[21].}$ The bases of the chambers were inserted into the soil between the rows and under the canopies of the tea plants to a depth of $5 \mathrm{~cm}$. The bases that had been inserted into the soil between the rows were removed prior to harvesting and fertilizer application, and then returned after the completion of these activities. Vials $(20 \mathrm{~mL})$ were vacuumed for $15 \mathrm{~min}$ before gas sampling. The $40 \mathrm{~mL}$ of air inside the chambers was collected with a $50-\mathrm{mL}$ syringe with a three-way cock. The gas samples in each chamber were collected two times at 20 min intervals, i.e., immediately after the closure of the chamber, and $20 \mathrm{~min}$ after placement. Air temperature was measured using an OPTEX thermometer (Optex Co. Ltd., Shiga, Japan) in each chamber.Gas and soil samples were collected once before fertilization and intensively after fertilization. Between fertilizations, gas samples were collected weekly in the growing season and monthly in the winter. The gas samples were taken between 11:00 am and 3:00 pm to measure the daily average gas emission in the field. The $\mathrm{N}_{2} \mathrm{O}$ concentration in the air samples were analyzed using a gas chromatograph (GC-2014, Shimadzu, Kyoto, Japan) equipped with an electron capture detector (ECD) held constant at $350{ }^{\circ} \mathrm{C}$. A carrier gas of $5 \%$ methane in argon was supplied at a flow rate of $10 \mathrm{~mL} \cdot \mathrm{min}^{-1}$. The injection temperature was $80^{\circ} \mathrm{C}$. The gas sampling started from 11 March 2014 to 22 December 2015.

Gas emissions were calculated from the change in the gas concentration in the chamber versus the closure time:

$$
F=\rho \times h \times(\triangle C / \triangle t) \times[273 /(273+T)]
$$

where $F$ is the gas flux $\left(\mu \mathrm{g} \cdot \mathrm{N} \cdot \mathrm{m}^{-2} \cdot \mathrm{h}^{-1}\right.$ for $\left.\mathrm{N}_{2} \mathrm{O}\right), \rho$ is the gas density $\left(\mathrm{N}_{2} \mathrm{O}-\mathrm{N}=1.26 \times 10^{9} \mu \mathrm{m}^{-3}\right)$, $h$ is the height of the chamber from the soil surface (m), $\triangle C / \triangle t$ is the slope of the change of the gas concentration inside the chamber during the sampling period $\left(\mathrm{m}^{3} \cdot \mathrm{m}^{-3} \cdot \mathrm{h}^{-1}\right)$, and $T$ is the average air temperature during the sampling period $\left({ }^{\circ} \mathrm{C}\right)$.

The emission factor (EF) is defined as the cumulative amount of $\mathrm{N}_{2} \mathrm{O}$ emitted from the fertilized treatment minus that from the control treatment and is expressed as a percentage of the $\mathrm{N}$ applied [8]. 
The equation used for the calculation cumulative amount of $\mathrm{N}_{2} \mathrm{O}$ is as follows:

$$
\text { Cumulative } \mathrm{N}_{2} \mathrm{O} \text { emission }=\sum_{i=0}^{n}\left(R_{i} \times 24 \times D_{i}\right)
$$

where $R_{i}$ is the mean gas flux $\left(\mathrm{mg} \cdot \mathrm{N} \cdot \mathrm{m}^{-2} \cdot \mathrm{h}^{-1}\right)$ of two successive sampling dates, $D_{i}$ is the number of days in the sampling interval and $\mathrm{n}$ is the number of sampling periods.

\subsection{Soil Sample Collection and Analysis}

Soil temperature was measured at a depth of $10 \mathrm{~cm}$ near the chamber. The volumetric soil water content was measured at a depth of $10 \mathrm{~cm}$ when the gas samples were collected, using a soil sensor (HydroSense CS 620 sensor, CD 620 display, Cambell Scientific, Inc., Logan, UT, USA). The volumetric soil water content was converted into WFPS using the following formula:

$$
\mathrm{WFPS}=\mathrm{Vol} /(1-\mathrm{SBD} / 2.65)
$$

where WFPS is the water-filled pore space (\%); Vol is the volumetric water content (\%); SBD is the soil bulk density $\left(\mathrm{g} \cdot \mathrm{cm}^{-3}\right)$; and 2.65 is the soil particle density $\left(\mathrm{g} \cdot \mathrm{cm}^{-3}\right)$.

Soil samples were collected from the rows in the different treatments at a depth of $0-10 \mathrm{~cm}$ at the same time as the gas sampling. Various physicochemical properties of the soil were measured, including $\mathrm{pH}$, total carbon concentration (TC), total nitrogen (TN), as well as the levels of nitrate $\left(\mathrm{NO}_{3}{ }^{-}\right)$, and ammonium $\left(\mathrm{NH}_{4}{ }^{+}\right)$ions. The procedures used for the laboratory analysis were as follows. The $\mathrm{pH}$ of 1:2.5 air-dried soil (weight) to deionized water (volume) (i.e., $20 \mathrm{~g}$ soil, $50 \mathrm{~mL}$ deionized water) was determined using a glass electrode. The concentrations of $\mathrm{NO}_{3}{ }^{-}-\mathrm{N}$ and $\mathrm{NH}_{4}{ }^{+}-\mathrm{N}$ were determined by extracting the mineral $\mathrm{N}$ in the soils with a $2 \mathrm{~mol} \cdot \mathrm{L}^{-1} \mathrm{KCl}$ solution (1:10 soil to $\mathrm{KCl}$ solution), which was then filtered through Whatman \#42 filter paper and analyzed using a colorimetric method. The absorbance of the extracted solution was measured using a dual wavelength spectrometric method and the indophenol blue method, respectively. For $\mathrm{NO}_{3}{ }^{-}$ concentration, no reagent was added to the $5 \mathrm{~mL}$ water samples and measurements were made directly at a wavelength of $220 \mathrm{~nm}$ and the absorbance of the extracted solution was measured using a UV-VIS spectrophotometer (Shimadzu UV mini 1240, Shimadzu Corporation, Kyoto, Japan). For $\mathrm{NH}_{4}{ }^{+}-\mathrm{N}$ analysis, $5 \mathrm{~mL}$ of the soil extract, $3 \mathrm{~mL}$ of buffer solution, and $2 \mathrm{~mL}$ of phenol-nitroprusside were mixed, and the absorbance of the mixed solution was measured after $45 \mathrm{~min}$ at a wavelength of $635 \mathrm{~nm}$ using a UV-VIS spectrophotometer (Shimadzu UV mini 1240, Shimadzu Corporation, Kyoto, Japan). Solution A contains $16 \mathrm{~g}$ of $\mathrm{NaOH}$ and $20 \mathrm{~mL}$ of $\mathrm{NaClO}$, which is prepared to obtain the final volume of 1 liter by adding distilled water. Solution $\mathrm{B}$ contains $30 \mathrm{~g} \mathrm{Na}_{2} \mathrm{HPO}_{4} 12 \mathrm{H}_{2} \mathrm{O}, 30 \mathrm{~g} \mathrm{C}_{6} \mathrm{H}_{5} \mathrm{Na}_{3} \mathrm{O}_{7} 2 \mathrm{H}_{2} \mathrm{O}$, $3 \mathrm{~g}$ EDTA2Na, $60 \mathrm{~g}$ phenol, and $0.02 \mathrm{~g} \mathrm{Na} 2 \mathrm{Fe}(\mathrm{CN})_{5} \mathrm{NO}_{2} \mathrm{H}_{2} \mathrm{O}$, which is prepared to obtain a final volume $1 \mathrm{~L}$ by adding distilled water. Total carbon and TN were measured using a Sumigraph NC-80 Auto Gas Chromatograph GC-4C device after the soil samples were sieved through a 0.5-mm mesh. The carbon:nitrogen ratio (C:N ratio) of the soil was used in subsequent analyses.

\subsection{Statistical Data Analysis}

Effects of fertilizer types on cumulative $\mathrm{N}_{2} \mathrm{O}$ were compared using a one-way analysis of variance, followed by Tukey's multiple comparisons test. Relationships between the environmental data and $\mathrm{N}_{2} \mathrm{O}$ fluxes were tested by correlation analysis by Pearson's correlation coefficient, respectively. All statistical analyses were performed using SigmaStat 3.5 statistical software (Systat Software Inc., San Jose, CA, USA). The cumulative amount of $\mathrm{N}_{2} \mathrm{O}$ emitted from the tea field was calculated usinga ratio of $1: 5$ for the row and canopy, corresponding to the row and canopy width. 


\section{Results}

\subsection{Environmental Factors}

Precipitation occurred intensively during June to September in both years, and the annual precipitation was $814 \mathrm{~mm}$ in 2014 and $829 \mathrm{~mm}$ in 2015 (Figure 1a). During the hot season (June-September), the mean air temperature was $28.0^{\circ} \mathrm{C}$ and the mean soil temperature was $22.7^{\circ} \mathrm{C}$. In the other seasons the mean air temperature was $19.6^{\circ} \mathrm{C}$ and $11.9^{\circ} \mathrm{C}$. The highest and lowest air temperatures were $40.1^{\circ} \mathrm{C}$ on 7 August and $10.4^{\circ} \mathrm{C}$ on $10 \mathrm{March}$, respectively (Figure 1b). Both soil and air temperatures were higher in rows than under the canopy. The mean WFPS was $20.2 \%$ in the soil of the rows and $9.8 \%$ in the soil under canopies. The WFPS under the canopy was lower than that of the rows. It started to increase from May until August, and was especially higher in the rainy season in 2015. The WFPS of rows was higher than under the canopies, but not significantly different in both 2014 and 2015. Those of rows were 13.5\% and 23.6\% in 2014 and 2015, respectively, and $11.4 \%$ and $6.5 \%$ under the canopies in 2014 and 2015, respectively. The WFPS of both rows and canopies in 2014 were lower than in 2015. Soil pH values in the soil under the canopy was higher than that of soil in the rows from the beginning of the experiment until spring fertilization in 2015, and they were not significantly different (Figure 1d).
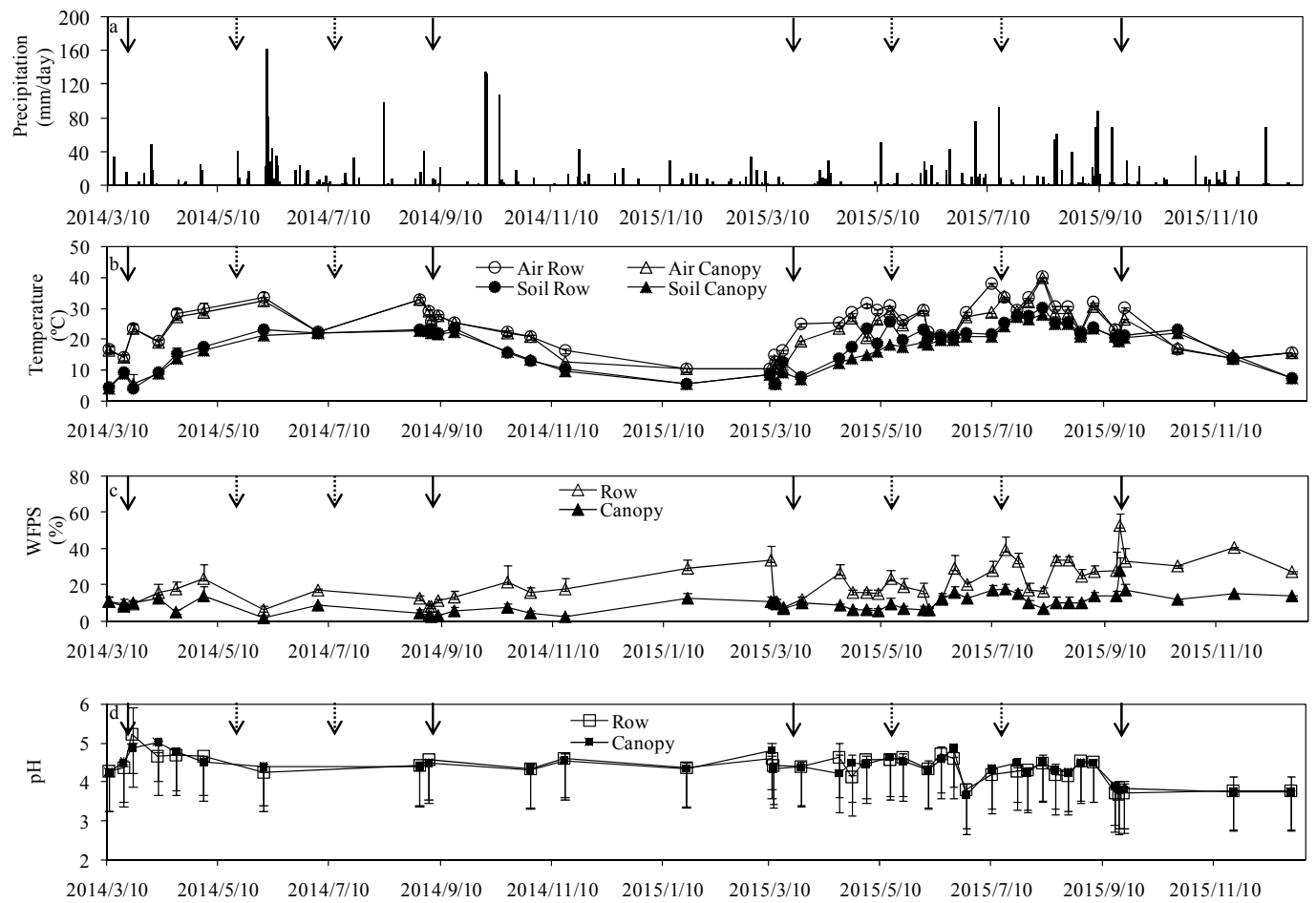

Figure 1. The patterns of (a) precipitation (b) soil temperature and air temperature; (c) WFPS and (d) $\mathrm{pH}$. Solid arrows and dotted arrows represent fertilization and tea harvest time, respectively.

There is no significant seasonal change in $\mathrm{NH}_{4}{ }^{+}-\mathrm{N}$ contents in CONT treatment, and no significant difference found between the $\mathrm{NH}_{4}{ }^{+}-\mathrm{N}$ contents of rows and under the canopy $(p>0.05)$ (Figure 2a). The $\mathrm{NH}_{4}{ }^{+}-\mathrm{N}$ contents in the soil of rows increased rapidly in the soil of rows after fertilizer applications in CRF and ORG treatments (Figure $2 \mathrm{~b}, \mathrm{c}$ ). The $\mathrm{NH}_{4}{ }^{+}-\mathrm{N}$ in the soil of rows were significantly higher than that under the canopy in CRF and ORG treatments $(p<0.05)$. There was no significant seasonal change in $\mathrm{NO}_{3}{ }^{-}-\mathrm{N}$ content in CONT treatment (Figure 3a), while there were significant seasonal changes in $\mathrm{NO}_{3}{ }^{-}-\mathrm{N}$ content during the whole experimental period in both CRF and ORG treatments (Figure 3b,c). The $\mathrm{NO}_{3}{ }^{-}-\mathrm{N}$ contents in the soil in 2014 did not increase in CRF and ORG treatments after spring and autumn fertilization, while gradually increasing from August, and reaching the highest level on 
4 September 2015. There was significant differencein $\mathrm{NO}_{3}{ }^{-}-\mathrm{N}$ contents in CRF treatment (Figure 3b), but no significant difference for ORG treatment $(p>0.05)$ (Figure 3c).
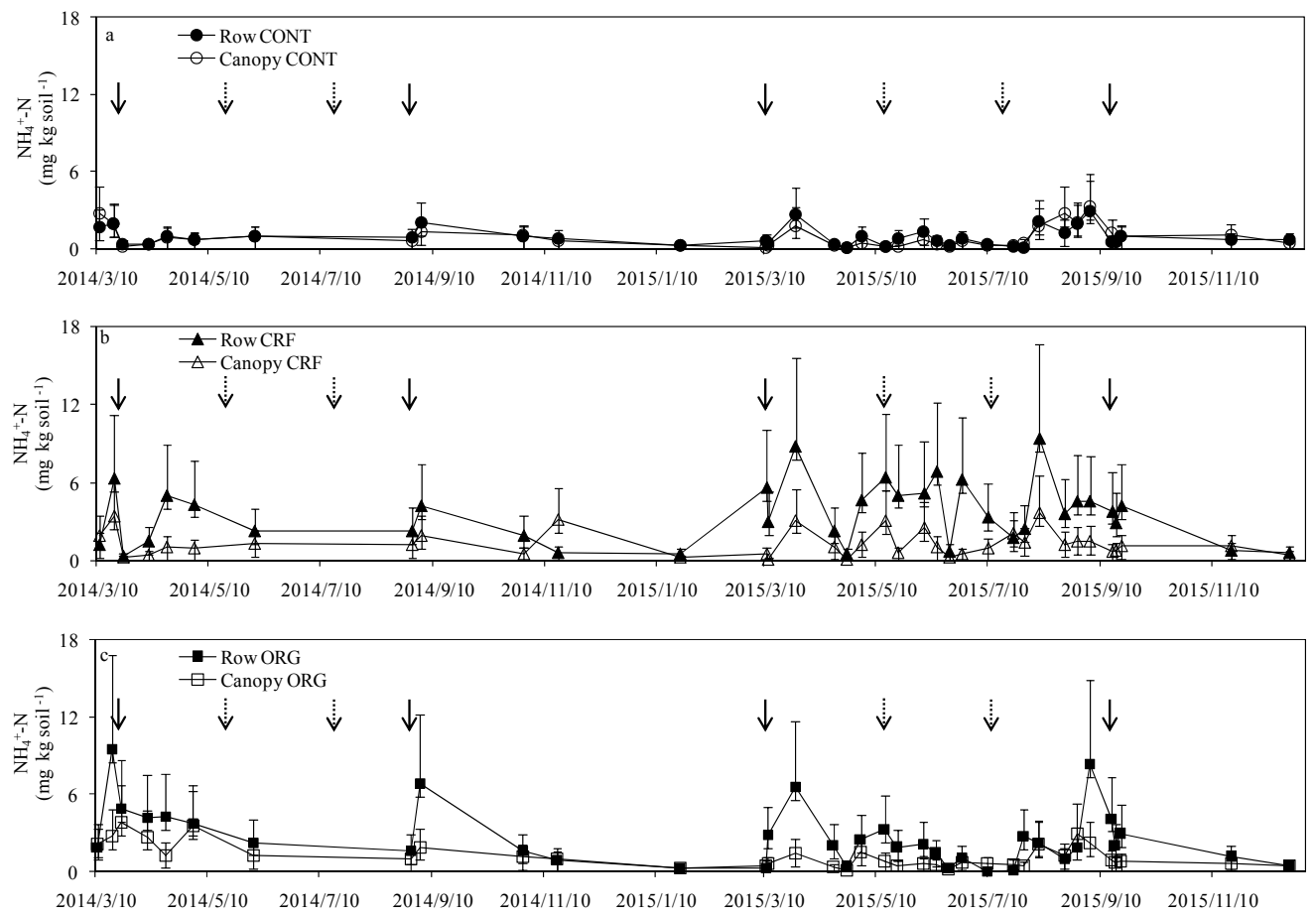

Figure 2. Time course of (a) $\mathrm{NH}_{4}{ }^{+}-\mathrm{N}$ in rows and under the canopy in CONT: no significance $(p>0.05)$; (b) $\mathrm{NH}_{4}{ }^{+}-\mathrm{N}$ in rows and under the canopy in CRF: significant difference $(p<0.05)$; and (c) $\mathrm{NH}_{4}{ }^{+}-\mathrm{N}$ in rows and under the canopy in ORG: significant difference $(p<0.05)$. Solid arrows and dotted arrows represent fertilization and tea harvest time, respectively.

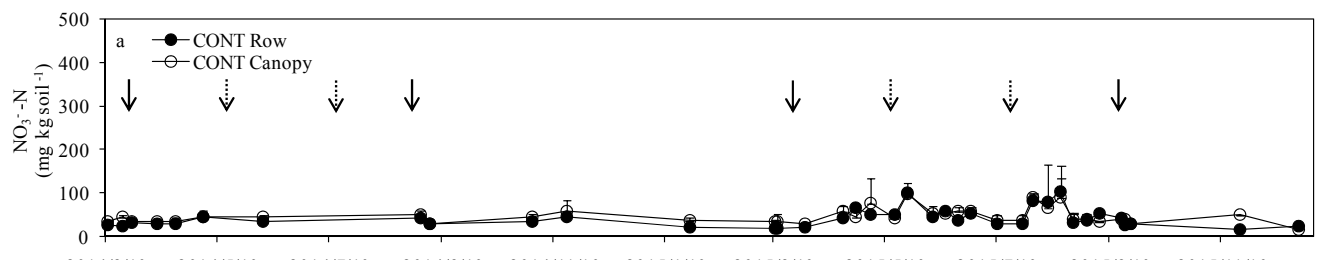

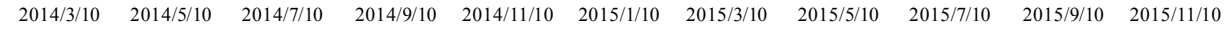
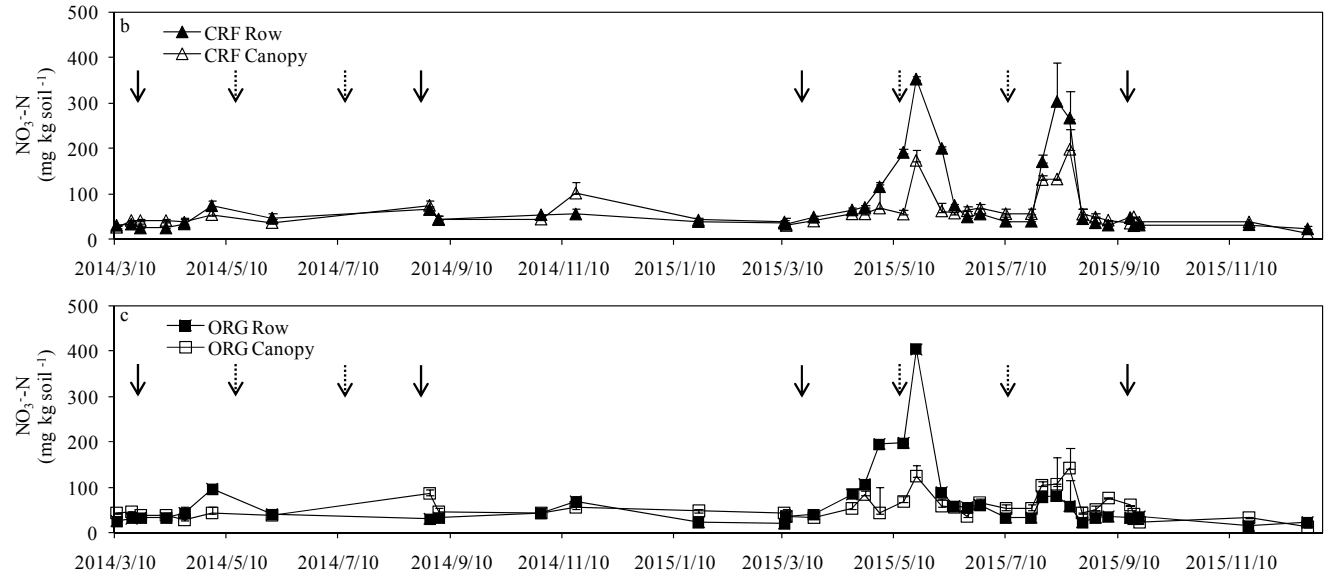

Figure 3. Time course of (a) $\mathrm{NO}_{3}{ }^{-}-\mathrm{N}$ in rows and under the canopy in CONT: no significant difference $(p>0.05) ;(\mathbf{b}) \mathrm{NO}_{3}{ }^{-}-\mathrm{N}$ in rows and under the canopy in CRF: significant difference $(p<0.05)$; and (c) $\mathrm{NO}_{3}{ }^{-}-\mathrm{N}$ in rows and under the canopy in ORG: no significant difference $(p>0.05)$. Solid arrows and dotted arrows represent fertilization and tea harvest time, respectively. 


\subsection{Nitrous Oxide Emission}

The $\mathrm{N}_{2} \mathrm{O}$ emissions in CONT treatment ranged from $-167.9 \mu \mathrm{g} \cdot \mathrm{m}^{-2} \cdot \mathrm{h}^{-1}$ to $162.5 \mu \mathrm{g} \cdot \mathrm{m}^{-2} \cdot \mathrm{h}^{-1}$ (Figure 4a). Several small emission peaks were observed in July and August 2015. There was no significant difference between the $\mathrm{N}_{2} \mathrm{O}$ emission in rows and under the canopy for CONT.There was no high $\mathrm{N}_{2} \mathrm{O}$ emission in CRF treatments after spring fertilization and $\mathrm{N}_{2} \mathrm{O}$ emission started to increase from the end of June (Figure $4 \mathrm{~b}$ ). After autumn fertilization, a high $\mathrm{N}_{2} \mathrm{O}$ emission peak with the value of $475.7 \mu \mathrm{g} \cdot \mathrm{m}^{-2} \cdot \mathrm{h}^{-1}$ was observed in 2014 in rows. In 2015, the $\mathrm{N}_{2} \mathrm{O}$ emissions in CRF treatment showed similar values with that of the CONT treatment. There was a significant difference between the $\mathrm{N}_{2} \mathrm{O}$ emission in rows and under the canopy in CRF treatment. A small $\mathrm{N}_{2} \mathrm{O}$ peak from the soil in rows occurred on 2 May and higher emission peaks from soil under the canopy were observed on 4 July in ORG treatment (Figure 4c). The highest amount of $\mathrm{N}_{2} \mathrm{O}$ in 2014 was emitted from soil in rows on 8 September, and from soil under the canopy on 17 September. The $\mathrm{N}_{2} \mathrm{O}$ emission peaks in ORG treatment gradually decreased from September to October. Nitrous oxide emission gradually increased from soil in rows in ORG treatment just after spring fertilization in 2015, then reached its second highest peak on 17 April with a value of $1161.1 \mu \mathrm{g} \cdot \mathrm{m}^{-2} \cdot \mathrm{h}^{-1}$, and then reached the highest peak in the whole experimental period on 24 April, with a value of $1158.0 \mu \mathrm{g} \cdot \mathrm{m}^{-2} \cdot \mathrm{h}^{-1}$ (Figure $4 \mathrm{c}$ ). During the intensive sampling period, which was started in June and ended in late September, $\mathrm{N}_{2} \mathrm{O}$ emission peaks were lower in ORG treatment compared with that of CRF treatment. In the whole experimental period, $\mathrm{N}_{2} \mathrm{O}$ emission in ORG treatment was significantly higher than that in CONT treatment $(p<0.05)$, and CRF treatment was not significantly different from CONT and ORG treatments $(p>0.05)$ (Figure 4a-c).
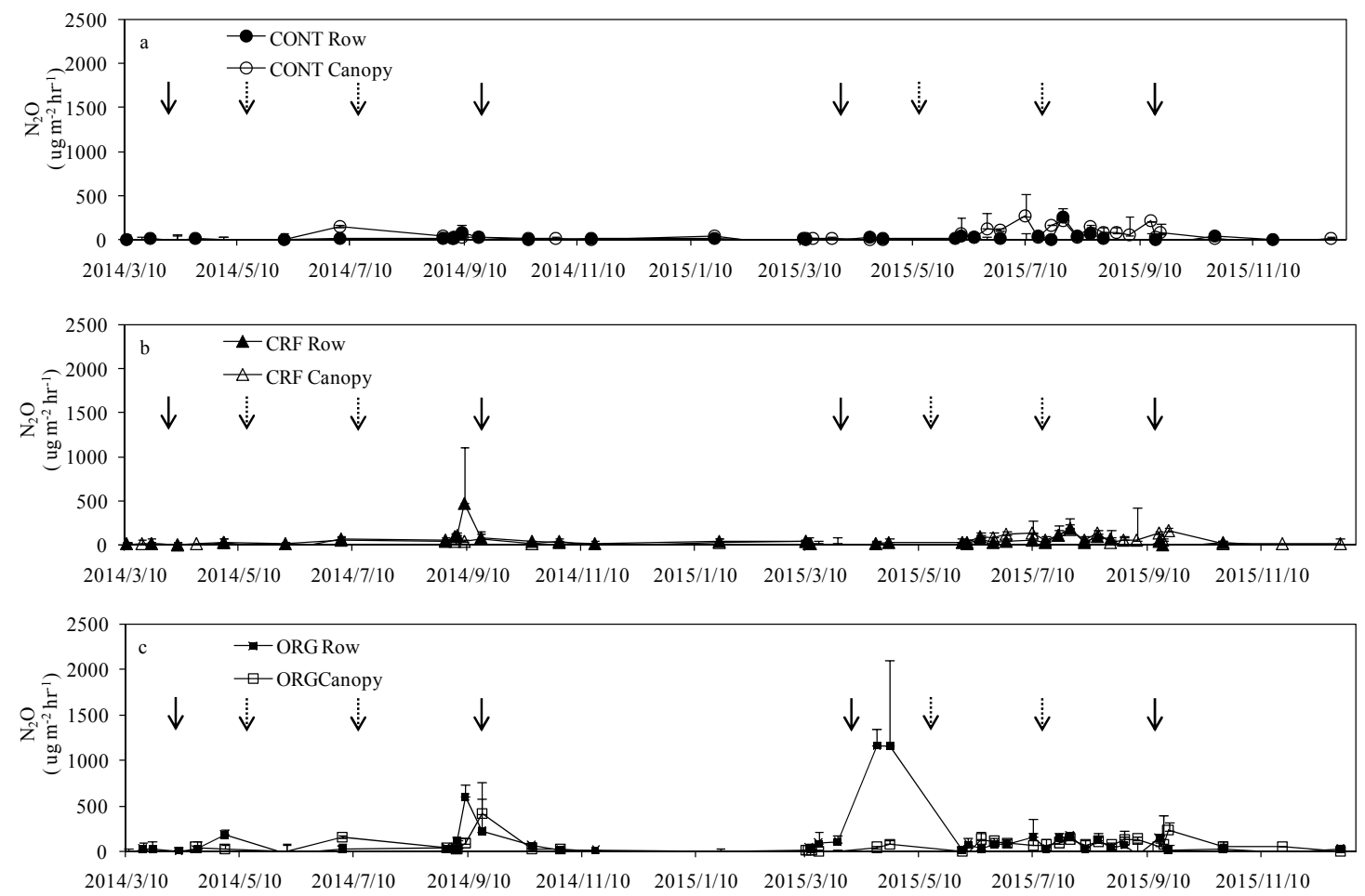

Figure 4. $\mathrm{N}_{2} \mathrm{O}$ emission from soil in rows and under the canopy. (a) CONT treatment: significant difference $(p<0.05)$; (b) CRF treatment: significant difference $(p<0.05)$; and (c) ORG treatment: significant difference $(p<0.05)$. Solid arrows and dotted arrows represent fertilization and tea harvest times, respectively.

Nitrous oxide emission was variably correlated with environmental data. In rows, $\mathrm{N}_{2} \mathrm{O}$ emission showed positive correlation with $\mathrm{NO}_{3}{ }^{-}-\mathrm{N}$ concentration $(p<0.05)$ (Table 3). For the canopy, 
$\mathrm{N}_{2} \mathrm{O}$ emission showed positive correlations with $\mathrm{NO}_{3}{ }^{-} \mathrm{N}(p<0.05), \mathrm{pH}$, air temperature, soil temperature, and soil moisture at different levels (Table 3 ).

Table 3. Correlation analysis between $\mathrm{N}_{2} \mathrm{O}$ emission $\left(\mu \mathrm{g} \cdot \mathrm{N} \cdot \mathrm{m}^{-2} \cdot \mathrm{h}^{-1}\right)$ and environmental data of the soil.

\begin{tabular}{|c|c|c|c|c|c|c|c|c|c|c|c|c|}
\hline & \multicolumn{2}{|c|}{$\begin{array}{c}\mathrm{NH}_{4}{ }^{+}-\mathrm{N} \\
\left(\mathrm{mg} \cdot \mathrm{kg}^{-1}\right)\end{array}$} & \multicolumn{2}{|c|}{$\begin{array}{c}\mathrm{NO}_{3}{ }^{-}-\mathrm{N} \\
\left(\mathrm{mg} \cdot \mathrm{kg}^{-1}\right)\end{array}$} & \multicolumn{2}{|c|}{$\mathrm{pH}$} & \multicolumn{2}{|c|}{$\begin{array}{l}\text { Air Temp. } \\
\quad\left({ }^{\circ} \mathrm{C}\right)\end{array}$} & \multicolumn{2}{|c|}{$\begin{array}{l}\text { Soil Temp. } \\
\left({ }^{\circ} \mathrm{C}\right)\end{array}$} & \multicolumn{2}{|c|}{ WFPS (\%) } \\
\hline & $R^{2}$ & $P$ & $R^{2}$ & $P$ & $R^{2}$ & $P$ & $R^{2}$ & $P$ & $R^{2}$ & $P$ & $R^{2}$ & $P$ \\
\hline Row & 0.50 & N.S. & 0.02 & $*$ & 0.61 & N.S. & 0.22 & N.S. & 0.64 & N.S. & 0.97 & N.S. \\
\hline Canopy & 0.13 & N.S. & 0.03 & * & 0.05 & * & 0.00 & $* * *$ & 0.00 & $* * *$ & 0.00 & $* *$ \\
\hline
\end{tabular}

Note: $\mathrm{NH}_{4}^{+}-\mathrm{N}$ and $\mathrm{NO}_{3}{ }^{-}-\mathrm{N}$ denotes ammonium-nitrogen and nitrate-nitrogen; WFPS means water filled pore space; ${ }^{* *}, * *, *$ and N.S. stand for significance at $0.1 \%, 1 \%, 5 \%$, and non-significant, respectively.

The annual cumulative $\mathrm{N}_{2} \mathrm{O}$ emissions in CRF were $10.8 \mathrm{~kg} \cdot \mathrm{N} \cdot \mathrm{ha}^{-1}$ and $12.8 \mathrm{~kg} \cdot \mathrm{N} \cdot \mathrm{ha}^{-1}$ in 2014 and 2015, respectively (Figure 5). The cumulative $\mathrm{N}_{2} \mathrm{O}$ emission in 2015 was $11.5 \%$ higher than that of 2014. The annual cumulative $\mathrm{N}_{2} \mathrm{O}$ emissions were $22.4 \mathrm{~kg} \cdot \mathrm{N} \cdot \mathrm{ha}^{-1}$ and $30.0 \mathrm{~kg} \cdot \mathrm{N} \cdot \mathrm{ha}^{-1}$ in 2014 and 2015 in ORG treatment, the cumulative $\mathrm{N}_{2} \mathrm{O}$ emission in 2015 was $33.9 \%$ higher than that of 2014 . In both 2014 and 2015, the cumulative $\mathrm{N}_{2} \mathrm{O}$ emissions in ORG treatments were significantly higher than that in CONT and CRF treatments $(p<0.05)$, while there were no significant differences between CONT and CRF treatments $(p>0.05)$.

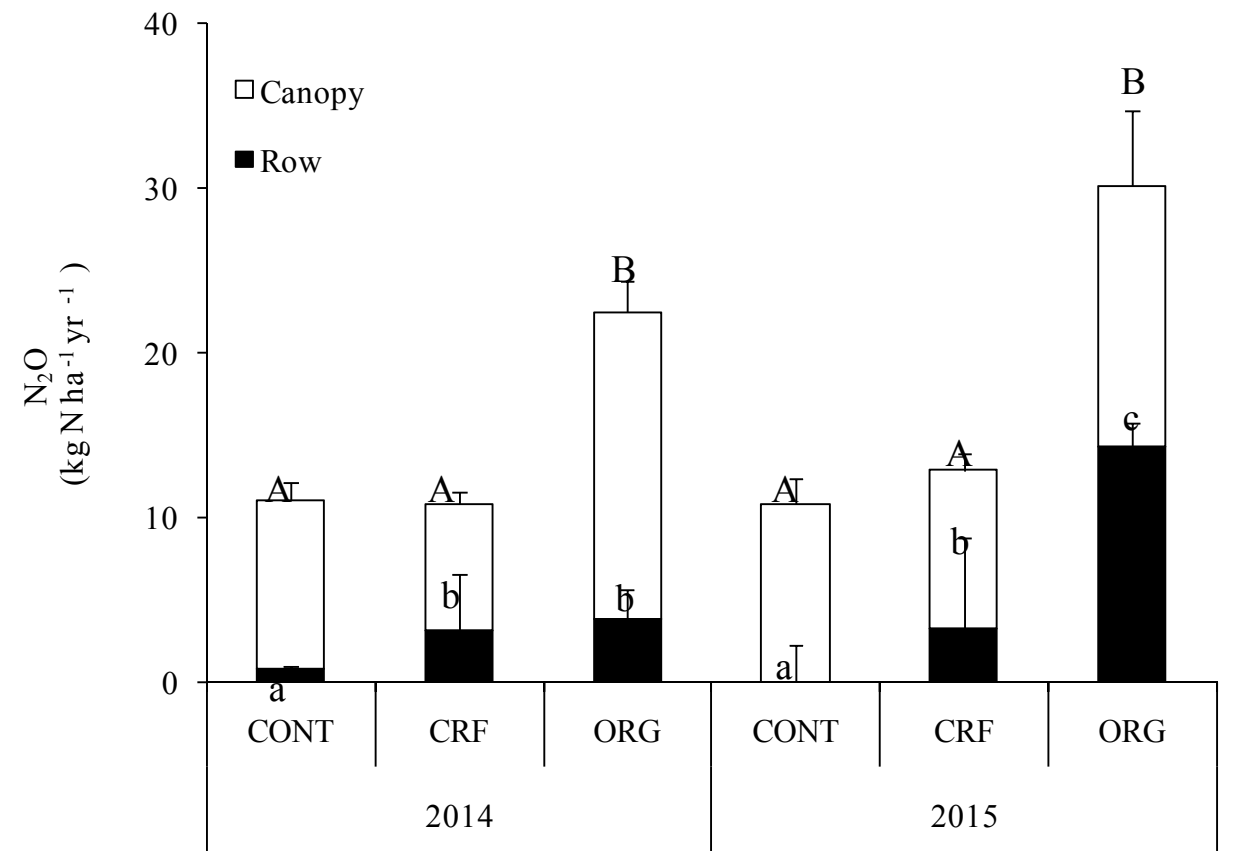

Figure 5. Annual cumulative $\mathrm{N}_{2} \mathrm{O}$ emission from different treatments in both 2014 and 2015. Different letters indicate a significant difference between different treatments or between rows and the canopy at $p<0.05$.

In 2014, the cumulative amounts of $\mathrm{N}_{2} \mathrm{O}$ from soil under the canopy were significantly higher in ORG treatment than that of CONT and CRF treatments (Figure 5). Cumulative $\mathrm{N}_{2} \mathrm{O}$ emission from the soil in rows was significantly lower in CONT than that of the two fertilized treatments. In 2015, the cumulative $\mathrm{N}_{2} \mathrm{O}$ emission from soil under the canopy was significantly higher in ORG treatment than that of CONT and CRF treatments, cumulative $\mathrm{N}_{2} \mathrm{O}$ emission from soil in rows in CRF was significantly higher than that in CONT treatment and significantly lower than that in ORG treatment. 
In the total two year monitoring period, $\mathrm{N}_{2} \mathrm{O}$ emissions were $18.7 \mathrm{~kg} \cdot \mathrm{N} \cdot \mathrm{ha}{ }^{-1}, 25.8 \mathrm{~kg} \cdot \mathrm{N} \cdot \mathrm{ha}^{-1}$, and $52.8 \mathrm{~kg} \cdot \mathrm{N} \cdot \mathrm{ha}^{-1}$ from CONT, CRF, and ORG, respectively. The $\mathrm{N}_{2} \mathrm{O}$ emission factors were $0.84 \%$ and $4.03 \%$ for CRF and ORG.

\section{Discussion}

\subsection{The Effects of Fertilizer on $\mathrm{N}_{2} \mathrm{O}$ Emission}

There were more seasonal fluctuations of $\mathrm{N}_{2} \mathrm{O}$ emission in ORG treatment compared with that in CONT and CRF treatments (Figure 4). The cumulative $\mathrm{N}_{2} \mathrm{O}$ emission from CRF was $51.1 \%$ lower than that of ORG. The results from this experiment indicated that CRF could mitigate $\mathrm{N}_{2} \mathrm{O}$ emission significantly compared with ORG fertilizer in both years (Figure 5). Coated urea is designed to release $\mathrm{N}$ gradually in response to moisture. Water passes by diffusion through pores in the sulfur coating and dissolves the urea, which can then diffuse back into the soil through the intact coating $[22,23]$. Rupturing of the coating may occur, and increased temperature enhances the rate of $\mathrm{N}$ release [24]. In this study, mineral $\mathrm{N}$ from the CRF and ORG treatments did not differ significantly throughout the sampling time (Figure 2b,c and Figure $3 b, c$ ). These results could be masked by water content and $\mathrm{pH}$ factors. Water content and $\mathrm{pH}$ are the important regulators to stimulate soil $\mathrm{N}_{2} \mathrm{O}$ emission [25]. The chicken manure and oil cake from ORG showed very high water content (22.4\% and $14.6 \%)$ and $\mathrm{pH}$ value (8.1 and 7.4, respectively). The WFPS and $\mathrm{pH}$ positively correlated with soil $\mathrm{N}_{2} \mathrm{O}$ emission (Table 3).

Although the mineral $\mathrm{N}$ in CRF treatment was not significantly lower than that of ORG treatment, cumulative $\mathrm{N}_{2} \mathrm{O}$ emission was significantly reduced by applying CRF fertilizer in a two year period (Figure 5).The results of this study are consistent with previous studies. Shoji and Kanno [26] conducted a field study and showed that the peak of $\mathrm{N}_{2} \mathrm{O}$ emissions after coated fertilizer application were $18 \%$ of the peak of $\mathrm{N}_{2} \mathrm{O}$ emission after conventional fertilizer application. As a result, the cumulative $\mathrm{N}_{2} \mathrm{O}$ emissions after coated fertilizer application for 70 days were $80 \%$ less than the cumulative $\mathrm{N}_{2} \mathrm{O}$ emissions after conventional fertilizer application. In this study, the highest peak in CRF treatment was only $475 \mu \mathrm{g} \cdot \mathrm{m}^{-2} \cdot \mathrm{h}^{-1}$, while the peak in ORG treatment reached $1161 \mu \mathrm{g} \cdot \mathrm{m}^{-2} \cdot \mathrm{h}^{-1}$ during two years of observation. Consequently, the cumulated $\mathrm{N}_{2} \mathrm{O}$ emission from controlled-release fertilizer was slightly higher than that of no fertilizer plots, and accounted for just $50 \%$ of total $\mathrm{N}_{2} \mathrm{O}$ emission from organic fertilizer treatments.

\subsection{The Effects of Row and Canopy on $\mathrm{N}_{2} \mathrm{O}$ Emissions}

In most sampling times, the $\mathrm{N}_{2} \mathrm{O}$ emissions from the soil on row were higher than that under the canopy throughout the whole experimental period for all treatments (Figure 4). One of the reasons could be explained by the higher soil and air temperature and soil WFPS in rows than under the canopy (Figure 1) since soil temperature and aerobic conditions are the major factors to regulate soil nitrification and denitrification processes $[27,28]$. Therefore, CONT with no fertilizer also found higher $\mathrm{N}_{2} \mathrm{O}$ emission in rows than that of the canopy. In the case of fertilizer treatments, both $\mathrm{NH}_{4}{ }^{+}-\mathrm{N}$ and $\mathrm{NO}_{3}{ }^{-}-\mathrm{N}$ concentrations on rows were higher than that under the canopy in $\mathrm{CRF}$ and ORG (Figures $2 \mathrm{~b}$ and $3 \mathrm{~b}$ ). The higher concentrations of $\mathrm{NH}_{4}{ }^{+}-\mathrm{N}$ and $\mathrm{NO}_{3}{ }^{-}-\mathrm{N}$ stimulated more $\mathrm{N}_{2} \mathrm{O}$ emissions by providing $\mathrm{N}$ sources for nitrification and denitrification processes $[27,29]$. Furthermore, tea root density under the canopy is higher than that in the rows, and the available $\mathrm{N}$ under the canopy is taken up by tea trees more than that of the rows [20]. Thus, the $\mathrm{N}_{2} \mathrm{O}$ emissions of rows were significantly higher than that under canopies (Figure 4).

The cumulative amount of $\mathrm{N}_{2} \mathrm{O}$ emitted from the tea field was calculated using a ratio of $1: 5$ for row and canopy, corresponding to the row and canopy width. Thus, even though the emission rate was lower for the canopy, the larger area would lead to the high cumulative amount. Many studies have founded that the canopy can contribute a large amount of $\mathrm{N}_{2} \mathrm{O}$ emission [20,21]. Our research also found that $\mathrm{N}_{2} \mathrm{O}$ emitted from the soil under the canopy was much higher than for rows (Figure 5). 
However, the $\mathrm{N}_{2} \mathrm{O}$ emitted from the soil under the canopy accounted for $71.7 \%$ and $75.2 \%$ of the whole emission in CRF in 2014 and 2015, respectively, while it accounted for $83.2 \%$ and 52.7\%, respectively, for ORG treatments. The significant difference in 2015 could be attributed to fertilizer formats. In CRF, the sulfur coating can improve soil moisture content $[10,24,30]$. As aresult, the higher $\mathrm{N}_{2} \mathrm{O}$ emission would be stimulated by the higher water concentration. From the observation in this research, the WFPS of soil under the canopy was increased $88.8 \%$ in 2015 compared with 2014 in CRF treatment, while the WFPS of the soil under the canopy was increased only $44.6 \%$ in ORG treatment (data did not showed). Consequently, the percentage of cumulative $\mathrm{N}_{2} \mathrm{O}$ emission from the soil under the canopy decreased in 2015 from $83.2 \%$ to $52.7 \%$ in ORG treatment.

Based on these results, it can be concluded that $\mathrm{N}_{2} \mathrm{O}$ emission from the canopy could not be ignored, even if there is no fertilizer applied. Thus, monitoring $\mathrm{N}_{2} \mathrm{O}$ emission from the soil under the canopy, as well as from soil between the rows, should be undertaken to determine the precise $\mathrm{N}_{2} \mathrm{O}$ emissions from tea fields under different fertilizer types.

\section{Conclusions}

This study showed that even though both ORG and CRF have slower $\mathrm{N}$ release compared to common chemical fertilizer, CRF significantly decreased $\mathrm{N}_{2} \mathrm{O}$ emission compared to organic fertilizer in tea fields. The main reason for this was not the release pattern, but the higher water content and $\mathrm{pH}$ value of ORG compared to CRF. Physiochemical characteristics of $\mathrm{N}$ amendments play a crucial role in controlling $\mathrm{N}_{2} \mathrm{O}$ emission from agricultural fields. In this study, we found that row area in tea fields had higher $\mathrm{N}_{2} \mathrm{O}$ emission than that of the canopy due to the higher soil temperature, lower moisture, and higher soil mineral $\mathrm{N}$ content. However, as the area of the canopy and row was considered, $\mathrm{N}_{2} \mathrm{O}$ emitted from the soil under the canopy accounted for over $70 \%$ of the whole emission in CRF and $52 \%-83 \%$ of ORG treatments in both years. This indicated $\mathrm{N}_{2} \mathrm{O}$ emission from the canopy could not be ignored, even when no fertilizer was applied. In quantification of the $\mathrm{N}_{2} \mathrm{O}$ emission from agricultural fields, the area must be categorized in its form of use and the emission must be measured for each form.

Acknowledgments: This research partly supported by Chinese Key Development Program (2016YFD0800805) and Shaoxing Science and technology project (2015B70025). Grant for Environmental Research Projects from the Sumitomo Foundation in Japan (153047) and the Funds for "Development of Human Resources in Science and Technology" Program to supporting research activities of female researchers (Hubs) (5570180505), the Ministry of Education, Culture, Sports, Science and Technology, Japan to N.O.O. The publication of this article was funded by the Open Access Fund of the Leibniz Association.

Author Contributions: In this study, Sonoko D. Bellingrath-Kimura and Tadashi Yokoyama designed the experiments; Ryosuke Omata, and Mudan Hou performed the experiments; the field management and data analysis conducted by Kenta Nakajima and Mudan Hou respectively; Naoko Ohkama-Ohtsu and Haruo Tanaka contributed reagents/materials/analysis tools; Sonoko D. Bellingrath-Kimuraand Meihua Deng wrote the paper.

Conflicts of Interest: The authors declare no conflict of interest.

\section{References}

1. MAFF (Ministry of Agriculture, Forestry and Fisheries). Tea and Fruit Cultivation Area in 2016. Available online: http:/ / www.e-stat.go.jp/SG1/estat/List.do?lid=000001172509 (accessed on 18 October 2016).

2. Mishima, S.; Kimura, S.D.; Eguchi, S.; Shirato, Y. Estimation of the amounts of livestock manure, rice straw, and rice straw compost applied to crops in Japan: A bottom-up analysis based on national survey data and comparison with the results from a top-down approach. Soil Sci. Plant Nutr. 2012, 58, 83-90. [CrossRef]

3. Tokuda, S.; Hayatsu, M. Nitrous oxide production from strongly acid tea field soils. Soil Sci. Plant Nutr. 2001, 46, 835-844. [CrossRef]

4. Xue, D.; Yao, H.Y.; Huang, C.Y. Microbial biomass, N mineralization and nitrification, enzyme activities, and microbial community diversity in tea orchard soils. Plant Soil. 2006, 288, 319-331. [CrossRef]

5. Li, Y.; Fu, X.Q.; Liu, X.L.; Shen, J.L.; Luo, Q.; Xiao, R.L.; Li, Y.Y.; Tong, C.L.; Wu, J.S. Spatial variability and distribution of $\mathrm{N}_{2} \mathrm{O}$ emissions from a tea field during the dry season in subtropical central China. Geoderma 2013, 193, 1-12. [CrossRef] 
6. Oh, K.; Kato, T.; Li, Z.P.; Li, F.Y. Environmental problems from tea cultivation in Japan and a control measure using calcium cyanamide. Pedosphere 2006, 16, 770-777. [CrossRef]

7. Nakasone, H.; Yamamoto, T. The impacts of the water quality of the inflow water from tea fields on irrigation reservoir ecosystems. Paddy Water Environ. 2004, 2, 45-50. [CrossRef]

8. Akiyama, H.; Yan, X.Y.; Yagi, K. Estimations of emission factors for fertilizer-induced direct $\mathrm{N}_{2} \mathrm{O}$ emissions from agricultural soils in Japan: Summary of available data. Soil Sci. Plant Nutr. 2006, 52, 774-787. [CrossRef]

9. NIES (National Institute for Environmental Studies). National Greenhouse Gas Inventory Report of Japan; Ministry of the Environment: Tsukuba, Japan, 2012.

10. Shaviv, A.; Mikkelsen, R.L. Controlled release fertilizers to increase efficiency of nutrient use and minimize environmental degradation: A review. Fertil. Res. 1993, 35, 1-12. [CrossRef]

11. Akiyama, H.; Yan, X.; Yagi, K. Evaluation of effectiveness of enhanced-efficiencyfertilizers as mitigation options for $\mathrm{N}_{2} \mathrm{O}$ and $\mathrm{NO}$ emissions from agricultural soils: Meta analysis. Glob. Chang. Biol. 2010, 16, 1837-1846. [CrossRef]

12. Lopez-Fernandez, S.; Diez, J.A.; Hernaiz, P.; Arce, A.; Garcia-Torres, L.; Vallejo, A. Effects of fertiliser type and the presence or absence of plants on nitrous oxide emissions from irrigated soils. Nutr. Cycl. Agroecosyst. 2007, 78, 279-289. [CrossRef]

13. Cheng, W.; Nakajima, Y.; Sudo, S.; Akiyama, H.; Tsuruta, $\mathrm{H} . \mathrm{N}_{2} \mathrm{O}$ and $\mathrm{NO}$ emissions from a field of Chinese cabbage as influenced by band application of urea or controlled-release urea fertilizers. Nutr. Cycl. Agroecosys. 2002, 63, 231-238. [CrossRef]

14. Ji, Y.; Liu, G.; Ma, J.; Xu, H.; Yagi, K. Effect of controlled-release fertilizer on nitrous oxide emission from a winter wheat field. Nutr. Cycl. Agroecosys. 2012, 94, 111-122. [CrossRef]

15. Ji, Y.; Liu, G.; Ma, J.; Zhang, G.B.; Xu, H.; Yagi, K. Effect of controlled-release fertilizer on mitigation of $\mathrm{N}_{2} \mathrm{O}$ emission from paddy field in South China: A multi-year field observation. Plant Soil 2013, 371, 473-486. [CrossRef]

16. Ball, B.C.; McTaggart, I.P.; Scott, A. Mitigation of greenhouse gas emissions from soil under silage production by use of organic manures or slow-release fertilizer. Soil Use Manag. 2004, 20, 287-295. [CrossRef]

17. Meijide, A.; Diez, J.A.; Sanchez-Martin, L.; Lopez-Fernandez, S.; Vallejo, A. Nitrogen oxide emissions from an irrigated maize crop amended with treated pig slurries and composts in a Mediterranean climate. Agric. Ecosyst. Environ. 2007, 121, 383-394. [CrossRef]

18. Chu, H.Y.; Hosen, Y.; Yagi, K. Nitrogen oxide emissions and soil microbial activities in a Japanese andisol as affected by N-fertilizer management. Soil Sci. Plant Nutr. 2004, 50, 287-292. [CrossRef]

19. Akiyama, H.; Morimoto, S.; Tago, K.; Hoshino, Y.T.; Nagaoka, K.; Yamasaki, M.; Karasawa, T.; Takenaka, M.; Hayatsu, M. Relationship between ammonia oxidizer and $\mathrm{N}_{2} \mathrm{O}$ and $\mathrm{CH}_{4}$ fluxes in agricultural fields with different soil types. Soil Sci. Plant Nutr. 2014, 60, 520-529. [CrossRef]

20. Hirono, Y.; Nonaka, K. Nitrous oxide emissions from green tea fields in Japan: Contribution of emissions from soil between rows and soil under the canopy of tea plants. Soil Sci. Plant Nutr. 2012, 58, 384-392. [CrossRef]

21. Hou, M.; Ohkama-Ohtsu, N.; Suzuki, S.; Tanaka, H.; Schmidhalter, U.; Bellingrath-Kimura, S.D. Nitrous oxide emission from tea soil under different fertilizer managements in Japan. Catena 2015, 135, 304-312. [CrossRef]

22. Trenkel, M.E. Improving Fertilizer Use Efficiency: Controlled-Release and Stabilized Fertilizers in Agriculture; International Fertilizer Industry Association: Paris, France, 1997.

23. Agrium, I. A New Generation in Smart Nitrogen: ESN Controlled-Release Fertilizer; Potato. Agrium Inc.: Calgary, AB, Canada, 2009.

24. Shaviv, A. Advances in controlled release of fertilizers. Adv. Agron. 2001, 71, 1-49.

25. Beauchamp, E.G. Nitrous oxide emission from agricultural soils. Can. J. Soil Sci. 1997, 77, 113-123. [CrossRef]

26. Shoji, S.; Kanno, H. Use of polyolefin-coated fertilizers for increasing fertilizerefficiency and reducing nitrate leaching and nitrous oxide emissions. Fertil. Res. 1994, 39, 147-152. [CrossRef]

27. Mosier, A.; Wassmann, R.; Verchot, L.; Khing, J.; Palm, C. Methane and nitrogen oxide fluxes in tropical agricultural soils. Environ. Dev. Sustain. 2004, 6, 11-49. [CrossRef]

28. Davidson, E.A. Sources of nitric oxide and nitrous oxide following wetting of dry soil. Soil Sci. Soc. Am. J. 1992, 56, 95-102. [CrossRef] 
29. Avrahami, S.; Conrad, R.; Braker, G. Effect of soil ammonium concentration on $\mathrm{N}_{2} \mathrm{O}$ release and on the community structure of ammonia oxidizers and denitrifiers. Appl. Environ. Microb. 2002, 68, 5685-5692. [CrossRef]

30. Shaviv, A. Plant response and environmental aspects as affected by rate and pattern of nitrogen release from controlled release N fertilisers. In Proceedings of the 8th Nitrogen Workshop "Progress in Nitrogen CyclingStudies", Ghent, Belgium, 5-8 September 1996; Kluwer Academ Pub: Dordrecht, The Netherlands; pp. 285-291.

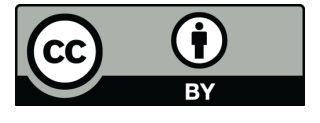

(C) 2017 by the authors. Licensee MDPI, Basel, Switzerland. This article is an open access article distributed under the terms and conditions of the Creative Commons Attribution (CC BY) license (http:/ / creativecommons.org/licenses/by/4.0/). 